\title{
CHANGES IN THE BLOOD FATTY-ACID PROFILE ASSOCIATED WITH OXIDATIVE-ANTIOXIDANT DISTURBANCES IN CORONARY ATHEROSCLEROSIS
}

\author{
PROMENE U PROFILU MASNIH KISELINA U KRVI POVEZANO SA \\ OKSIDATIVNO-ANTIOKSIDATIVNIM POREMEĆAJIMA KOD KORONARNE ATEROSKLEROZE
}

\author{
Yuliya I. Ragino1, Viktoriya S. Shramko 1, Ekaterina M. Stakhneva1, Elena I. Chernyak², \\ Sergey V. Morozov², Elena V. Shakhtshneider 1,4, Yana V. Polonskaya?, \\ Liliia V. Shcherbakova ${ }^{1}$, Alexander M. Chernyavskiy ${ }^{3}$ \\ ${ }^{1}$ Institute of Internal and Preventive Medicine (branch of Institute of Cytology and Genetics), \\ Siberian Branch of Russian Academy of Sciences (IIPM - Branch of IC\&G SB RAS), Novosibirsk, Russia \\ ${ }^{2}$ N. N. Vorozhtsov Institute of Organic Chemistry of Siberian Branch of Russian Academy of Sciences \\ (NIOCH SB RAS), Novosibirsk, Russia \\ ${ }^{3}$ Federal Publicly Funded Institution Meshalkin National Medical Research \\ Center of the Ministry of Health of the Russian Federation, Novosibirsk, Russia \\ ${ }^{4}$ Novosibirsk State University, Novosibirsk, Russia
}

\section{Summary}

Background: The objective of this work was to study the profile of fatty acids and to search for associations of fatty acids with oxidative-antioxidant parameters and an oxidative-inflammatory biomarker (lipoprotein-associated phospholipase A2) in men with coronary atherosclerosis and coronary heart disease.

Methods: Analysis of 20 fatty acids was performed in 60 men with angiographically confirmed coronary atherosclerosis and coronary heart disease and in a control group of men without coronary heart disease. Serum fatty-acid content was evaluated by high-performance gas-liquid chromatography. The blood levels of oxidative stress, total antioxidative defence, and lipoprotein-associated phospholipase 2 were analyzed.

Results: In the group of men with coronary atherosclerosis the levels of myristic and palmitic fatty acids were higher by $59 \%$ and $22 \%$, respectively. An increase in the weight percentage of monounsaturated fatty acids was noted, such as palmitoleic, oleic, and octadecenic. Significantly lower levels of polyunsaturated fatty acids, such as linolic, eicosadienoic, eicosatrienoic, arachidonic, eicosapentaenoic, $\gamma$ linolenic, docosapentaenoic, and docosahexaenoic were

Address for correspondence:

Elena Shakhtshneider

175/1Bogatkova Str., Novosibirsk 630004, Russia

Phone: +7 (383) 264-2516

Fax: +73832642516

e-mail: 2117409@mail.ru,niitpm.office@gmail.com

\section{Kratak sadržaj}

Uvod: Cilj ovog rada bio je da se ispita profil masnih kiselina $\mathrm{i}$ da se istraže veze masnih kiselina sa oksidativnoantioksidativnim parametrima i oksidativno-inflamatornim biomarkerom (lipoprotein - udružena fosfolipaza A2) kod muškaraca sa koronarnom aterosklerozom i koronarnom bolešću srca.

Metode: Sprovedena je analiza 20 masnih kiselina kod 60 muškaraca sa angiografski potvrđenom koronarnom aterosklerozom i koronarnom bolešću srca i kod kontrolne grupe muškaraca bez koronarne bolesti srca. Sadržaj masnih kiselina u serumu je procenjen gasnom-tečnom hromatografijom visokih performansi. Analizirani su nivoi oksidativnog stresa u krvi, ukupne antioksidativne odbrane i lipoproteinasocirane fosfolipaze A2.

Rezultati: U grupi muškaraca sa koronarnom aterosklerozom, nivo mirističkih i palmitinskih masnih kiselina bio je veći za $59 \%$ i $22 \%$, respektivno. Uočen je porast u težinskom procentu mononezasićenih masnih kiselina, kao što su palmitoleinska, oleinska i oktadeceinska. U grupi sa koronarnom arterosklerozom otkriveni su znatno niži nivoi polinezasićenih masnih kiselina, kao što su linolna, eikosadienoična, eikosatrienoična, arahidonska, eikos-

List of abbreviations: AT, Agilent Technologies; CA, Coronary atherosclerosis; CBS, Coronary bypass surgery; CHD, Coronary heart disease; FA, Fatty acid; FORD, Free Oxygen Radicals Defense; FORT, Free Oxygen Radicals Testing; HDL, High-density lipoproteins; LDL, Low-density lipoprotein; Lp-PLA2, Lipoprotein-associated phospholipase A2; Me, Median; MUFA, Monounsaturated fatty acid; PUFA, Polyunsaturated fatty acid; SFA, Saturated fatty acids; VSMCs, Vascular smooth muscle cells. 
detected in the group with coronary atherosclerosis. The lipoprotein-associated phospholipase A2 level was higher by $48 \%$. Oxidative stress was higher by $17 \%$, and the total antioxidant defence in serum was lower by $45 \%$. We found correlations between fatty acids and oxidative-antioxidative alterations. The relative risk of vulnerable atherosclerotic plaques correlated with increased levels of palmitic, stearic, oleic, and linolic fatty acids.

Conclusions: Significant alterations in the profile of fatty acids are associated with oxidative-antioxidative alterations and are accompanied by an increase in free-radical formation, which can probably serve as a risk factor of atherosclerosis.

Keywords: atherosclerosis, atherosclerotic plaque, fatty acid, lipid, lipoprotein-associated phospholipase 2, oxidative stress

\section{Introduction}

There is significant interest in the problem of lipid accumulation in the arterial wall in atherosclerosis. However, some aspects concerning both the mechanisms of atherosclerotic lesions of arterial vessels and the causes of dyslipidemia remain unclear. Studies that are intended to reveal the role of fatty acids (FAs) in the pathogenesis of atherosclerosis have been growing in number, and priority is given to the separate contribution of every FA instead of the whole set of FAs (1-7). FAs are believed to play a dual role in atherogenesis. Saturated FAs (SFAs) increase the risk of cardiovascular disease, whereas unsaturated FAs suppress atherosclerosis development, and the latter effect is associated not only with a reduction in the total cholesterol level but also with a shift of some cholesterol into high-density lipoproteins (HDLs) and accumulation of polyunsaturated FAs (PUFAs) inside phospholipids in cells $(1,5,8)$. Thus, a modification of the FAs composition of the blood can play an important role in the pathogenesis of atherosclerosis. Lipoprotein-associated phospholipase A2 (Lp-PLA2), an enzyme whose increased level in the circulation is linked with a high risk of atherosclerotic-plaque destabilization, is being actively studied. Besides, this enzyme has been suggested to be a highly specific marker of intravascular inflammation (9).

The present study was aimed at investigating the balance of FAs, the search for associations of FAs with oxidative-antioxidant parameters and oxidativeinflammatory biomarker LP-FLA2 in men with coronary atherosclerosis $(C A)$ and coronary heart disease (CHD).

\section{Materials and Methods}

This study was conducted within the framework of R\&D topics of Government contracts No. 03242018-0002 and 0324-2017-0048 and with the financial support of RFBR grant No. 17-04-02120. apentaenska, $\gamma$-linolenska, dokosapentaenoična i dokosaheksaenoična. Nivo lipoprotein-asocirane fosfolipaze A2 bio je viši za 48\%. Oksidativni stres je bio veći za 17\%, a ukupna antioksidativna odbrana u serumu bila je niža za 45\%. Pronašli smo korelacije između masnih kiselina i oksidativno-antioksidativnih promena. Relativni rizik od nestabilnih aterosklerotskih plakova korelira sa povećanim nivoima palmitinske, stearinske, oleinske i linolne masne kiseline.

Zaključak: Značajne promene u profilu masnih kiselina povezane su sa oksidativno-antioksidativnim promenama i praćene su porastom formiranja slobodnih radikala, što verovatno može da posluži kao faktor rizika za aterosklerozu.

Ključne reči: ateroskleroza, aterosklerotski plak, masne kiseline, lipid, lipoprotein-asocirane fosfolipaze A2, oksidativni stres

The study protocol was approved by the local Ethics Committee of the Institute of Internal and Preventive Medicine (a branch of the Institute of Cytology and Genetics, the Siberian Branch of the Russian Academy of Sciences, Novosibirsk, Russia). Each patient gave written informed consent to be examined and to participate in the study.

The study was carried out in the two groups comparable by sex, age $(56.38 \pm 8.5)$, and without metabolic syndrome. Study exclusion criteria were acute infectious inflammatory diseases, and exacerbation of chronic conditions, renal failure, active hepatic disorders, and cancer, taking steroid and nonsteroidal anti-inflammatory drugs. In addition, the experimental group exclusion criteria included myocardial infarction that happened less than 6 months ago. The experimental group consisted of 60 patients with $\mathrm{CHD}$, angiographically confirmed $\mathrm{CA}$, with stable effort angina, and without the acute coronary syndrome, who were admitted to the hospital for coronary bypass surgery (CBS) in Meshalkin National Medical Research Center of the Ministry of Health of the Russian Federation. The patients underwent endarterectomy in coronary arteries in the course of CBS by intraoperative indications. All the endarterectomy samples were sent for histological analysis. The control group consisted of 20 peers without CHD. The presence of CHD was excluded in the control group based on clinical examination and exercise testing.

Collection of blood samples from the basilic vein was performed in both the experimental (before CBS) and control group after overnight fasting for a minimum of 12 hours and after overnight rest, restraining from physical exercises, smoking, and alcohol for at least $12 \mathrm{~h}$ before laboratory measurements. These were determined in the blood serum: 20 FAs, triglycerides, FORD, FORT, Lp-PLA2. The FAs profile of all the samples was determined after extraction and methanolysis by high-performance capillary gas-liquid chromatography on an Agilent Technologies (AT) 
$6890 \mathrm{~N}$ chromatograph with a plasma ionization detector and by chromatography with mass spectrometry on an AT $6890 \mathrm{~N}$ chromatograph with massselective detector AT $5975 \mathrm{~N}$. The study included SFAs, such as myristic (C 14:0), pentadecanoic (C 15:0), palmitic (C 16:0), steatic (C 18:0), arachic (C 20:0), and docosanoic (C 22:0), and unsaturated FAs, such as palmitoleic (C 16:1), oleic (C 18:1), octadecenic (C 18:1), eicosenoic (C 20:1), docosanoic (C 22:1), linoleic (C 18:2, $\omega-6), \alpha$-linolenic (C 18:3, $\omega-3), \gamma$-linolenic (C 18:3, $\omega-6)$, eicosadienoic (C 20:2, $\omega-6$ ), eicosatrienoic (C 20:3, $\omega-6$ ), eicosapentaenoic (C 20:5, $\omega-3$ ), docosapentaenoic (C 22:5, $\omega-3$ ), docosahexaenoic (C 22:6, $\omega-3$ ), and arachidonic (C 20:4, $\omega-6$ ). The quantitative assessment of FAs was made in relation to their total amount.

Triglyceride content of blood was evaluated by an enzyme method using Thermo Fisher Scientific kits on a KonelabPrime 30i biochemical analyzer (Thermo Fisher Scientific, Finland). Oxidative stress (test FORT - Free Oxygen Radicals Testing) and total antioxidative defence in the blood (test FORD - Free Oxygen Radicals Defense) were evaluated using a FORM Plus CR3000 analyzer (Callegary, Italy). The level of oxidative stress (test FORT) was evaluated as a release of active oxygen forms by colourimetric registration. This method is based on the ability of metal ions to catalyze the formation of free radicals in the presence of hydroperoxides. Test FORD is based on the assessment of decreased absorption of previously formed active radicals, which is proportional to the concentration of the antioxidants in the blood. The concentration of Lp-PLA2 in serum was evaluated by an enzyme immunoassay with an ELISA kit (CloudClone Corp., USA).

Histological analysis of the pieces of intimamedia coronary arteries was performed under a binocular microscope Axiostar Plus after a macroscopic sample characterization (possible expansion of an atherosclerotic plaque, the degree of artery luminal occlusion, areas of calcification, and thrombi), standard hematoxylin-eosin staining, and Van Gieson's staining. Vulnerable atherosclerotic plaques were identified via the following criteria: a damaged plaque with a fibrous cap less than $65 \mu \mathrm{m}$, infiltrated by macrophages and $T$ lymphocytes (more than 25 cells per field of view $0.3 \mathrm{~mm}$ ), with a large lipidic nucleus (>40\%) (10). According to the results of the histological analysis of intima-media pieces, $53.2 \%$ of the patients had vulnerable atherosclerotic plaques in coronary arteries (subgroup A), whereas $46.8 \%$ patients were found to have only stable atherosclerotic plaques (subgroup B).

Statistical analysis of the results was performed in the SPSS software (version 20.0). Median (Me) and interquartile ranges $(25 \%$; $75 \%)$ of various parameters are presented in tables. The Kolmogorov-
Smirnov test was conducted for the assessment of the data distribution. The nonparametric criterion was used to compare two groups by the Mann-Whitney test in case of a non-normal distribution. In addition, multivariate logistic regression analysis was performed. Spearman's test assessed correlations. Differences were considered statistically significant at $\mathrm{p}<0.05$.

\section{Results}

In total, 20 FAs were identified in the serum samples, including six SFAs and 14 unsaturated FAs (Table I). Comparative analysis showed significant elevation of SFA levels in the group of patients with $\mathrm{CHD}$ and $\mathrm{CA}$ in comparison with the patients without CHD, mainly owing to an increase of the myristic acid level by $59 \%(p<0.01)$ and the palmitic acid level by $22 \%$ $(p<0.01)$. The weight proportion of stearic acid had only a slight tendency to be elevated in the group with $\mathrm{CHD}$ and $\mathrm{CA}$. When we studied the content of MUFAs, we found a significant increase in the mass proportion of palmitoleic acid (by $52 \%, \mathrm{p}<0.01$ ), oleic acid (by 38\%, $\mathrm{p}<0.01$ ), and octadecenoic acid (by $25 \%, p<0.05$ ) in the group of patients with atherosclerosis.

The percentages of omega-3 FAs ( $\alpha$-linolenic, eicosapentaenoic, docosapentaenoic and docosahexaenoic) were significantly lower (Table I) compared with the control group. The level of eicosapentaenoic acid decreased by $22 \%$, the level of docosapentaenoic acid by $28 \%$, and that of docosahexaenoic acid by $33 \%(p<0.05)$. Although the level of $\alpha$-linolenic acid decreased 3.3-fold, it did not show any statistically significant difference from the control group which was probably due to the small sample size of patients.

We also revealed a statistically significant decrease in the proportion of omega- 6 PUFAs in the experimental group. The weight proportion of linolic acid was lower by $25 \%$, of eicosadienoic acid by $21 \%$, and arachidonic acid by $44 \%(\mathrm{p}<0.01)$. It should be mentioned that the eicosatrienoic acid level decreased by $15 \%$, while the $\gamma$-linolenic acid level decreased by $32 \%$ in men with atherosclerosis.

In our study, patients with CA and CHD, as expected, had significantly higher triglyceride levels (by $68 \%, \mathrm{p}<0.05$ ) as compared with the control group (Table II). As expected, in the analysis of inflammation and oxidative-stress biomarkers, it was found that the indicator of oxidative stress (test FORT) was higher by $17 \%$ in the experimental group $(p<0.05)$, while the overall degree of antioxidant protection (test FORD) was lower by $45 \%(p<0.01)$ compared with the control group (Table II).

In addition, the concentration of the principal enzyme of phospholipid hydrolysis, Lp-PLA2, was 
Table I Weight percentages of FAs in the serum of men with CA and CHD, and in their peers without CHD.

\begin{tabular}{|c|c|c|c|}
\hline Fatty acids & $\begin{array}{l}\text { Patients with CHD and coronary } \\
\text { atherosclerosis } \mathrm{Me}(25 \% ; 75 \%), \%\end{array}$ & $\begin{array}{c}\text { Patients without CHD Me } \\
(25 \% ; 75 \%), \%\end{array}$ & Value \\
\hline \multicolumn{4}{|c|}{ Saturated fatty acids } \\
\hline Myristic (C 14:0) & $0.94(0.75 ; 1.28)$ & $0.59(0.48 ; 0.92)$ & $<0.01$ \\
\hline Pentadecanoic (C 15:0) & $0.25(0.17 ; 0.29)$ & $0.32(0.18 ; 0.39)$ & - \\
\hline Palmitic (C 16:0) & $26.84(25.43 ; 29.27)$ & $22.08(19.12 ; 24.48)$ & $<0.01$ \\
\hline Stearic (C 18:0) & $7.89(7.19 ; 8.71)$ & $7.72(7.21 ; 9.53)$ & - \\
\hline Arachic (C 20:0) & $0.37(0.15 ; 0.49)$ & $0.29(0.17 ; 0.52)$ & - \\
\hline Docosanoic (C 22:0) & $0.09(0.08 ; 0.11)$ & $0.12(0.09 ; 0.18)$ & - \\
\hline \multicolumn{4}{|c|}{ Monounsaturated fatty acids } \\
\hline Palmitoleic (C 16:1) & $2.48(0.19 ; 2.69)$ & $1.63(1.01 ; 2.12)$ & $<0.01$ \\
\hline Oleic (C 18:1) & $23.02(21.45 ; 24.60)$ & $16.73(15.31 ; 20.49)$ & $<0.01$ \\
\hline Octadecenic (C 18:1) & $3.79(3.21 ; 4.39)$ & $3.03(2.54 ; 3.76)$ & $<0.05$ \\
\hline Eicosenoic (C 20:1) & $0.27(0.20 ; 0.33)$ & $0.25(0.16 ; 0.57)$ & - \\
\hline Docosanoic (C 22:1) & $0.14(0.10 ; 0.19)$ & $0.14(0.11 ; 0.37)$ & - \\
\hline \multicolumn{4}{|c|}{ Polyunsaturated fatty acids } \\
\hline Linolic (C 18:2, $\omega-6)$ & $24.07(22.34 ; 27.64)$ & $32.32(27.63 ; 34.24)$ & $<0.01$ \\
\hline$\gamma$-linolenic (C 18:3, $\omega-6)$ & $0.29(0.22 ; 0.37)$ & $0.43(0.26 ; 0.68)$ & $<0.05$ \\
\hline$\alpha$-linolenic (C 18:3, $\omega-3)$ & $0.90(0.84 ; 1.07)$ & $2.95(0.61 ; 10.75)$ & - \\
\hline Eicosadienoic (C 20:2, $\omega-6$ ) & $0.33(0.28 ; 0.39)$ & $0.42(0.34 ; 0.55)$ & $<0.01$ \\
\hline Eicosatrienoic (C 20:3, $\omega-6$ ) & $1.22(1.02 ; 1.47)$ & $1.43(1.24 ; 1.68)$ & $<0.05$ \\
\hline Arachidonic (C 20:4, $\omega-6)$ & $3.29(2.38 ; 4.84)$ & $5.88(4.35 ; 7.29)$ & $<0.01$ \\
\hline Eicosapentaenoic (C 20:5, $\omega-3$ ) & $0.45(0.31 ; 0.65)$ & $0.58(0.49 ; 0.81)$ & $<0.05$ \\
\hline Docosapentaenoic (C 22:5, $\omega-3$ ) & $0.31(0.19 ; 0.41)$ & $0.43(0.35 ; 0.56)$ & $<0.01$ \\
\hline Docosahexaenoic (C 22:6, $\omega-3)$ & $1.22(0.87 ; 1.69)$ & $1.81(1.50 ; 2.13)$ & $<0.01$ \\
\hline
\end{tabular}

Table II Triglyceride levels, characteristics of oxidative stress and of antioxidant defense, and Lp-PLA2 levels in the serum of patients with $\mathrm{CA}$ and $\mathrm{CHD}$, and in their peers without $\mathrm{CHD}$.

\begin{tabular}{|l|c|c|c|}
\hline Characteristics & $\begin{array}{c}\text { Patients with CHD and coronary } \\
\text { atherosclerosis Me }(25 \% ; 75 \%), \%\end{array}$ & $\begin{array}{c}\text { Patients without CHD Me } \\
(25 \% ; 75 \%), \%\end{array}$ & value \\
\hline Triglycerides $(\mathrm{mmol} / \mathrm{L})$ & $1.66(1.27 ; 2.18)$ & $0.99(0.82 ; 1.46)$ & $<0.05$ \\
\hline Lp-PLA2 $(\mathrm{ng} / \mathrm{mL})$ & $109.91(66.58 ; 188.27)$ & $74.04(44.42 ; 98.89)$ & $<0.05$ \\
\hline FORT $(\mathrm{mmol} / \mathrm{L})$ & $2.27(1.64 ; 2.76)$ & $1.94(1.47 ; 2.39)$ & $<0.05$ \\
\hline FORD $(\mathrm{mmol} / \mathrm{L})$ & $0.59(0.25 ; 0.80)$ & $1.08(0.82 ; 1.28)$ & $<0.01$ \\
\hline
\end{tabular}


Table III Logistic regression analysis of a relative risk of the presence of vulnerable atherosclerotic plaques in coronary arteries in relation to FAs.

\begin{tabular}{|l|c|c|c|c|}
\hline \multirow{2}{*}{ Fatty acids } & \multirow{2}{*}{$\operatorname{Exp}(\mathrm{B})$} & \multicolumn{2}{|c|}{$95.0 \%$ C.I. for Exp(B) } & \multirow{2}{*}{$\mathrm{p}$} \\
\cline { 3 - 4 } & & Lower & Upper & \\
\hline Myristic (C 14:0) & 1.179 & 0.039 & 35.930 & 0.925 \\
\hline Pentadecanoic (C 15:0) & 0.540 & 0.015 & 19.069 & 0.734 \\
\hline Palmitic (C 16:0) & 16.591 & 2.011 & 136.866 & 0.009 \\
\hline Stearic (C 18:0) & 6.308 & 1.112 & 35.766 & 0.037 \\
\hline Palmitoleic (C 16:1) & 0.267 & 0.010 & 7.322 & 0.435 \\
\hline Oleic (C 18:1) & 6.751 & 1.358 & 33.568 & 0.020 \\
\hline Eicosenic (C 20:1) & 1462.15 & 0.000 & $49 \mathrm{E9}$ & 0.410 \\
\hline Linolic (C 18:2, $\omega-6)$ & 7.522 & 1.497 & 37.804 & 0.014 \\
\hline$\gamma$-linolenic (C 18:3, $\omega-6)$ & 51.836 & 0.003 & $8 \mathrm{E} 5$ & 0.422 \\
\hline Eicosadienoic (C 20:2, $\omega-6)$ & $18 \mathrm{E} 5$ & 0.001 & $23 \mathrm{E} 14$ & 0.177 \\
\hline Arachidonic (C 20:4, $\omega-6)$ & 2.928 & 0.567 & 15.111 & 0.200 \\
\hline Eicosatrienoic (C20:3, $\omega-6)$ & 62.413 & 0.499 & 7806.245 & 0.093 \\
\hline Eicosapentaenoic (C 20:5, $\omega-3)$ & 1.830 & 0.001 & 4850.686 & 0.881 \\
\hline Docosapentaenoic (C 22:5, $\omega-3)$ & 23132.16 & 0.001 & $61 \mathrm{E} 10$ & 0.249 \\
\hline Docosahexaenoic (C22:6, $\omega-3)$ & 38.256 & 0.654 & 2237.713 & 0.079 \\
\hline Patient age & 0.939 & 0.779 & 1.132 & 0.511 \\
\hline
\end{tabular}

higher by $48 \%(p<0.05)$ in the circulation in men with $\mathrm{CA}$ and $\mathrm{CHD}$ in comparison with the control group. This enzyme is directly involved in atherogenesis by oxidizing free FAs as well as by inducing oxidation of free FAs, lipid modification, and initiation of intravascular inflammation (9).

Correlation analysis showed direct correlations of the triglyceride level with myristic and palmitic FAs $(r=0.422, r=0.248, p<0.05$, respectively $)$ and with palmitoleic and oleic FAs $(r=0.455, r=0.561$, $\mathrm{p}<0.01$, respectively). We revealed negative correlations between triglycerides and PUFAs, such as linolic $(r=-0.454, p<0.01)$ and arachidonic $(r=0.258$, $\mathrm{p}<0.05)$.

When conducting a correlation analysis between the weight proportion of individual FAs with parameters FORT, FORD, and Lp-PLA2, we identified a negative correlation between $\gamma$-linolenic acid and LpPLA2 $(r=-0.224, p<0.05)$; between FORT and $\gamma$-linolenic, arachidonic, docosapentaenoic, and docosahexaenoic acids $(r=-0.288,-0.283,-0.230$, and $-0.259, \mathrm{p}<0.05$, respectively); and between FORD and myristic, palmitic, palmitoleic, and oleic acids $(r=-0.224, p<0.05 ; r=-0.427,-0.465$, and $-0.398, p<0.01$, respectively). We also uncovered positive associations between octadecenoic acid and Lp-PLA2 ( $r=0.233, p<0.05)$; between FORT and oleic, octadecenoic, and eicosenic acids $(r=0.237$, 0.359 , and 0.378, respectively, $\mathrm{p}<0.05$ ); and between linolic acid and FORD $(r=0.468, p<0.01)$.

The data on patients with CA and CHD were processed using multivariate logistic regression analysis. The presence of vulnerable atherosclerotic plaques in coronary arteries was considered a dependent variable. All of the studied FAs and the age of the patients served as independent variables (Table III). The results indicated that the relative risk of the presence of vulnerable atherosclerotic plaques in coronary arteries was associated with increased levels of palmitic, stearic, oleic, and linolic acids.

For an increase in the palmitic acid weight percentage by $1 \%$, the risk of formation of vulnerable plaques increased 16 -fold $(p<0.01)$. For an increase in the weight percentage of stearic or oleic acid by $1 \%$, the risk increased more than sixfold $(p<0.05)$. For an increase in the linolic acid level by $1 \%$, the risk of formation of vulnerable atherosclerotic plaques increased 7.5-fold $(p<0.01)$. 


\section{Discussion}

SFAs with a long and medium carbon chain are constituents of lipoproteins and circulate in the blood. These SFAs are used for the synthesis of other lipoid compounds in the body, e.g., cholesterol and LDL, and therefore SFAs are associated with an increased risk of cardiovascular disease (1). Nonetheless, there are studies showing that SFAs have no significant association with the risk of $\operatorname{CHD}(11,13)$.

Our data on the changes in the levels of SFAs are consistent with the previously obtained results of Chen $X$. et al. (3), who revealed that the level of palmitic acid (from 16:0) was eightfold higher, and the level of stearic acid (from 18:0) was threefold higher in patients with atherosclerosis compared to the levels of these acids in the control group. These FAs have been identified as potential biomarkers for the clinical diagnosis of atherosclerosis. A number of researchers have suggested that high levels of palmitic acid may initiate the processes of inflammation and apoptosis $(14,15)$.

Unsaturated FAs are subdivided according to the degree of unsaturation into monounsaturated (MUFAs) and polyunsaturated fatty acids (PUFAs).

We detected a significant increase in the concentration of MUFAs, owing to oleic and palmitoleic acid, in patients with atherosclerosis. This change could switch vascular smooth muscle cells (VSMCs) from the contractile to synthetic type and stimulate VSMC proliferation and migration in the subendothelium, which contributes to the formation of an organized atherosclerotic plaque $(16,17)$.

During a comparison of the effects PUFAs on atherosclerosis and CHD risk, it is important to distinguish between omega-3 and omega-6 PUFAs. Omega-3 PUFAs are traditionally considered protective factors, which are associated with a decreased risk of cardiovascular disease $(4,5)$. Despite the lack of a direct association between a high level of omega3 FAs and a lower risk of CHD in several studies, there is an association with a decrease in total mortality (2). Moreover, there are studies showing that treatment with omega-3 FAs significantly decreases triglyceride levels in blood among men with hyperlipidemia $(3,6$, $7,12,13)$. According to our data, the triglyceride content in the control group is lower, and PUFA levels are much higher.

Our results on the relation of low levels of omega-6 PUFAs with coronary artery disease and atherosclerosis are consistent with the findings of $L$. Wang et al. (18), who have also shown the relation between low levels of omega-6 PUFAs and the development of CHD.

The changes of the decrease in the content of individual PUFAs in the blood serum in patients with atherosclerosis (owing to increased lipid peroxidation processes, which most strongly affect PUFAs) underlines the importance of oxidative stress in the pathogenesis of $\operatorname{CHD}(14,15)$.

To date, only a few researchers have studied the association of omega- 6 and omega-3 PUFAs with LpPLA2 concentration and activity. In our study, we detected a negative association of omega- 6 PUFAs ( $\gamma$-linolenic) with Lp-PLA2; these data are partially consistent with the results of Steffen et al. (19). Unlike us, Schmidt et al. (20), observed the opposite relation: a correlation of omega-3 PUFA levels (EPA and DHA; rather than omega-6) with Lp-PLA2 concentration.

We determined that high levels of SFAs and MUFAs can contribute to blockage of the absorption of linoleic and linolenic LDL by the cell and a deficiency of PUFAs in the cell. These problems may promote the atherosclerotic process.

Considering the identified correlations, it is possible that during atherosclerosis in the human body, triglycerides contain mainly palmitic, oleic, myristic, and palmitoleic FAs.

The uncovered moderate negative correlations of PUFAs with biomarkers of inflammation and oxidative stress suggest that a decrease in the level of these FAs is accompanied by an increase in free-radical formation. The latter can probably increase the risk of atherosclerosis.

\section{Conclusion}

Thus, individual contributions of 20 FAs to atherogenesis were analyzed in patients with atherosclerosis. Increased levels of SFAs and MUFAs, such as myristic, palmitic, palmitoleic, oleic and octadecenic, were detected in blood serum. Furthermore, significant downregulation of all the studied omega-3 and omega-6 PUFAs was uncovered. These alterations are prominent and associated with signs of oxidative-antioxidative imbalance in the blood and an increased concentration of an oxidative-inflammation biomarker, Lp-PLA2. The relative risk of the presence of vulnerable atherosclerotic plaques in coronary arteries is associated with higher levels of palmitic, stearic, oleic, and linolic acids.

These findings probably indicate that alterations in the profile of FAs are accompanied by an increase in free-radical formation, which can probably serve as a risk factor of atherosclerosis.

\section{Ethics approval and consent to participate}

The study protocol was approved by the local Ethics Committee of the Institute of Internal and Preventive Medicine (a branch of the Institute of 
Cytology and Genetics, the Siberian Branch of the Russian Academy of Sciences, Novosibirsk, Russia). Written informed consent to be examined and to participate in the study was obtained from each patient.

\section{Availability of data and material}

The datasets before and after analysis in this study are available from the corresponding author on reasonable request.

\section{Funding}

This study was conducted within the framework of R\&D topics of Government contracts No. 0324- 20180002 and 0324-2017-0048 and with financial support of RFBR grant No. 17-04-02120.

Acknowledgements. The English language was corrected and certified by shevchuk-editing.com. The authors thank the patients for participation in this study.

\section{Consent for publication}

All the authors meet the International Committee of Medical Journal Editors (ICMJE) criteria for authorship for this manuscript, take responsibility for the integrity of the work as a whole, and have given final approval to the version to be published.

\section{References}

1. Kleber ME, Delgado GE, Dawczynski C, Lorkowski S, März W, Von Schacky C. Saturated fatty acids and mortality in patients referred for coronary angiography - The Ludwigshafen Risk and Cardiovascular Health study. J Clin Lipidol 2018; 12(2): 455-63. doi: 10.1016/j.jacl. 2018.01.007.

2. Hamazaki K, Iso H, Eshak ES, Ikehara S, Ikeda A, Iwasaki M, Hamazaki T, Tsugane S, JPHC Study Group. Plasma levels of $n-3$ fatty acids and risk of coronary heart disease among Japanese: The Japan Public Health Center-based (JPHC) study. J Atherosclerosis 2018; 272: 226-32. doi: 10.1016/j.atherosclerosis.2017.12.004.

3. Chen X, Liu L, Palacios G, Gao J, Zhang N, Li G, Lu J, Song $\mathrm{T}$, Zhang $\mathrm{Y}, \mathrm{L} v \mathrm{H}$. Plasma metabolomics reveals biomarkers of the atherosclerosis. J Sep Sci 2010; 33(17-18): 2776-83. doi: 10.1002/jssc.201000395.

4. Zehr KR, Walker MK. Omega-3 polyunsaturated fatty acids improve endothelial function in humans at risk for atherosclerosis: A review. J. Prostaglandins Other Lipid Mediat 2018; 134: 131-40. doi: 10.1016/j.prostaglandins.2017.07.005. PMCID: PMC5803420.

5. Bäck M. Omega-3 fatty acids in atherosclerosis and coronary artery disease. Future Sci OA 2017; 3(4): FSO236. doi: 10.4155/fsoa-2017-0067.PMCID: PMC5674268.

\section{Competing interests}

The authors declare that they have no conflicts of interest associated with publication of this article. Authors' contributions Yuliya I. Ragino: study conception and design and critical revision of the manuscript Viktoriya S. Shramko: analysis and interpretation of the biochemical data, literature review, drafting of the manuscript, and participation in discussion Ekaterina M. Stakhneva: collection of the clinical data, analysis and interpretation of the data on oxidative stress (test FORT) and total antioxidative defense in blood (test FORD), and literature review Elena V. Chernyak: analysis and interpretation of the data of chromatographic analysis Sergey V. Morozov: analysis and interpretation of the data of chromatographic analysis and participation in discussion Elena V. Shakhtshneider: revision of the manuscript and participation in discussion Yana V. Polonskaya: a collection of the clinical data, analysis and interpretation of the enzyme immunoassay data, and drafting of the manuscript Liliia V. Shcherbakova: statistical analysis Alexander M. Chernyavskyi: a collection of the clinical data, analysis and interpretation of the data on all endarterectomy samples from patients with angiographically confirmed CA, and participation in discussion.

\section{Conflict of interest statement}

The authors stated that they have no conflicts of interest regarding the publication of this article.

6. Oh PC, Koh KK, Sakuma I, Lim S, Lee Y, Lee S, Lee K, Han SH, Shin EK. Omega- 3 fatty acid therapy dosedependently and significantly decreased triglycerides and improved flow-mediated dilation, however, did not significantly improve insulin sensitivity in patients with hypertriglyceridemia. Int J Cardiol 2014; 176(3): 696-702. doi: 10.1016/j.ijcard.2014.07.075.

7. Siasos G, Tousoulis D, Oikonomou E, Zaromitidou M, Verveniotis A, Plastiras A, Kioufis S, Maniatis K, Miliou A, Siasou Z, Stefanadis C, Papavassiliou AG. Effects of Omega-3 fatty acids on endothelial function, arterial wall properties, inflammatory and fibrinolytic status in smokers: a cross over study. Int. J. Cardiol 2013; 166(2): 340-6. doi: 10.1016/j.ijcard.2011.10.081.

8. Waddington El, Croft KD, Sienuarine K, Latham B, Puddey IB. Fatty acid oxidation products in human atherosclerotic plaque: an analysis of clinical and histopathological correlates. J Atherosclerosis 2003; 167(1): 11120. doi: https://doi.org/10.1016/S0021-9150(02) 00391-X.

9. Keles EM, Samadi A, Isikhan YS, Sener ZY, Sezgin A, Keles E, Lay I, Canpolat U. The effect of effort test on the levels of ischemia modified albumin, 7 ketocholesterol and cholestan-3 $3,5 \alpha, 6 \beta$-triol and their role in the diagnosis of coronary artery disease. J Med Biochem 2019; 38: 249-55. 
10. Waksman R, Seruys PW. Handbook of the vulnerable plaque. London; 2004. pp.1-48.

11. Chowdhury R, Warnakula S, Kunutsor S, Crowe F, Ward HA, Johnson L, Franco OH, Butterworth AS, Forouhi NG, Thompson SG, Khaw KT, Mozaffarian D, Danesh J, Di Angelantonio E. Association of dietary, circulating and supplement fatty acids with coronary risk: a systematic review and meta-analysis. Ann Intern Med 2014; 160(6): 398-406. doi: 10.7326/M13- 1788.

12. Harris WS, Bulchandani D. Why do omega-3 fatty acids lower serum triglycerides? Curr Opin Lipidol 2006; 17(4): 387-393. doi: 10.1097/01.mol.0000236363.63840.16.

13. Wang DD, Li Y, Chiuve SE. Stampfer MJ, Manson JE, Rimm EB, Willett WC, Hu FB. Association of specific dietary fats with total and cause-specific mortality. JAMA Intern Med 2016; 176(8): 1134-1145 .doi: 10.1001/ jamainternmed.2016.2417. PMCID: PMC5123772.

14. Itakura $H$, Yokoyama $M$, Matsuzaki $M$, Saito $Y$, Origasa $\mathrm{H}$, et al. Relationships between plasma fatty acid composition and coronary artery disease. J Atheroscler Thromb 2011, 18: 99-107. doi: 10.5551/jat.587

15. Ninić A, Bogavac-Stanojević N, Sopić M, Munjas J, Kotur-Stevuljević J, Miljković M, Gojković T, Kalimanovska-Oštrić D, Vesna Spasojević-Kalimanovska. Superoxide dismutase isoenzymes gene expression in peripheral blood mononuclear cells in patients with coronary artery disease. J Med Biochem 2019; 38: 284-91.
16. Warensjo E, Sundstrom J, Vessby B, Cederholm T, Riserus $U$. Markers of dietary fat quality and fatty acid desaturation as predictors of total and cardiovascular mortality: a population-based prospective study. Am J Clin Nutr 2008, 88(1): 203-9. doi:10.1093/ajcn/88.1.203

17. Sun LB, Zhang $Y$, Wang $Q$, Zhang $H, X u$ W, Zhang J, Xiang J, Li QG, Xiang Y, Wang DJ, Zhang CY. Serum palmitic acid-oleic acid ratio and the risk of coronary artery disease: a case-control study. J Nutr Biochem 2011, 22(4): 311-7. doi: 10.1016/j.jnutbio.2010.02.009.

18. Wang L, Folsom AR, Eckfeldt JH. Plasma fatty acid composition and incidence of coronary heart disease in middle aged adults: the Atherosclerosis Risk in Communities (ARIC) Study. Nutr Metab Cardiovasc Dis 2003, 13(5): 256-66. doi.org/10.1016/S0939-4753(03)80029-7.

19. Brian TS, Lyn MS, Shuang L, Russell T, Nancy SJ, Michael Y. Tsai n-3 and n-6 Fatty acids are independently associated with lipoprotein-associated phospholipase A2 in the Multi-Ethnic Study of Atherosclerosis. British Journal of Nutrition. 2013, 110: 1664-71. doi:10. 1017/S0007114513000949

20. Schmidt EB, Koenig W, Khuseyinova N, et al. Lipoprotein-associated phospholipase A2 concentrations in plasma are associated with the extent of coronary artery disease and correlate to adipose tissue levels of marine omega-3 fatty acids. Atherosclerosis 2008, 196(1): 420-4. doi:10.1016/j.atherosclerosis.2006.11.027

Received: December 29, 2018

Accepted: February 24, 2019 